\title{
Article \\ Selected Elements in the Soils Covering Mass Graves from World Wars I and II in Southeastern Poland
}

\author{
Józef Żychowski (1)
}

Citation: Żychowski, J. Selected Elements in the Soils Covering Mass Graves from World Wars I and II in Southeastern Poland. Minerals 2021, 11, 275. https://doi.org/10.3390/ $\min 11030275$

Academic Editor: Yuri Lopes Zinn

Received: 15 January 2021

Accepted: 3 March 2021

Published: 8 March 2021

Publisher's Note: MDPI stays neutral with regard to jurisdictional claims in published maps and institutional affiliations.

Copyright: (C) 2021 by the author. Licensee MDPI, Basel, Switzerland. This article is an open access article distributed under the terms and conditions of the Creative Commons Attribution (CC BY) license (https:// creativecommons.org/licenses/by/ $4.0 /)$.
Faculty of Exact and Natural Sciences, Institute of Geography, Pedagogical University of Krakow, Podchorążych 2, 30-084 Kraków, Poland; jozef.zychowski@up.krakow.pl

\begin{abstract}
This study evaluates the reasons for the different content of eight selected elements, $\mathrm{Cu}, \mathrm{Pb}$, $\mathrm{Zn}, \mathrm{S}, \mathrm{K}, \mathrm{Na}, \mathrm{Ca}$ and $\mathrm{P}$, in the upper sections of soil profiles covering mass graves in southeastern Poland. The burial sites include 18 mass graves from World Wars I and II, an active parish cemetery, an old kirkut (Jewish cemetery) and, as a comparative site, a forest nursery. Chemical analyses were carried out using atomic absorption spectroscopy. Among the elements were $\mathrm{P}$ and $\mathrm{Ca}$, which dominate in the soils covering the burial sites from World War II. Higher amounts of the elements analysed were found at sites where many people were buried in a small area. The burial sites dug in pure sand revealed a lower content of the elements analysed, particularly Ca and P. In places where human ashes were scattered, $\mathrm{Ca}$ and $\mathrm{P}$ prevailed. The comparative site, a wet forest margin, is characterized by low levels of $S$ and relatively higher amounts of $C$ a and $P$. In the soils covering World War I graves $\mathrm{P}$, in particular, prevails over $\mathrm{Zn}, \mathrm{Pb}$ and $\mathrm{Cu}$. Differences in the concentrations of the elements studied depend on the type and age of the burial site, the type of soil, the slope gradient and water content prevailing at the site and the proximity to mass graves and cemeteries found close to each other.
\end{abstract}

Keywords: elements; $\mathrm{Ca}$; $\mathrm{P}, \mathrm{Zn}, \mathrm{Cu}, \mathrm{Pb}, \mathrm{K}, \mathrm{Na}, \mathrm{S}$; mass graves; soil

\section{Introduction}

Favourable carbon (30), nitrogen (3) and phosphorus (1) ratios noted for vertebrate bodies encourage rapid degradation of corpses [1,2]. Other factors also affect decomposition [3]: (i) growth of microbes and their activity; (ii) availability of carbon, nitrogen, phosphorus and sulphur; (iii) a high water content of a corpse; (iv) neutral pH conditions; (v) warm temperatures; (vi) well-drained soil; and (vii) burial practice-depth of the burial, construction and material of the coffin, etc.

The ratio of organic to inorganic phosphorus in soils varies with depth. Down to approximately $20 \mathrm{~cm}$ of the soil profile, organic-bound phosphorus, i.e., the phosphorus associated with plant debris and soil organic matter, comprises $75 \%$ of the total P content. Below this humus-rich layer, the contribution of organic phosphorus rapidly decreases [4]. Phosphorus is concentrated in soils in the same places as organic matter [5-9]. Phosphorus may leach rather quickly in sandy soils containing low amounts of other elements stabilizing phosphorus [10]. In contrast, in weakly permeable soils, e.g., loamy varieties, $\mathrm{P}$ migrates downward to a maximum depth of $40 \mathrm{~cm}$, even with intensive fertilization and watering [11].

Inorganic phosphorus is also adsorbed, particularly on the surfaces of clay minerals where ion complexes form [12-15]. Phosphate ions are bound to clay minerals where they replace hydroxyl ions $\left(\mathrm{OH}^{-}\right)$. In the initial stage of the exchange, thin layers of phosphates cover the surfaces of clay minerals. It is at this stage that the phosphate anions are again replaced by hydroxyls, and for a period of time, both anion types remain in equilibrium [16]. Over time and with higher amounts of phosphates, the latter build more stable, crystalline structures also containing $\mathrm{Fe}$ and $\mathrm{Al}$ [15]. In the presence of $\mathrm{Ca}^{2+}$, calcium phosphates 
are formed irrespective of the $\mathrm{pH}$ of the environment [17]. Thus, the existence of calcium cations prevents the leaching of phosphate anions.

Such a regular phosphorus distribution in soils may be affected by the presence of numerous burial sites, as phosphorus is a natural component of bones [18-20]. This study focuses on the elements $\mathrm{Cu}, \mathrm{Pb}, \mathrm{Zn}, \mathrm{K}, \mathrm{Na}$ and $\mathrm{S}$, as well as on $\mathrm{Ca}$ and $\mathrm{P}$, which form can accumulate as a result of the demineralization of bones and can be found in soils covering burial sites. The released phosphorus reacts with the available metals and forms phosphides, which represent the third state of oxidation.

Sulphur is another element that controls the process of bone decomposition. Considering the presence of many elements in the burial environment, including elements derived from decomposing corpses, new compounds may form in the soil, such as metal sulphides and hydrogen sulphide [21]. This study limits its investigation to $S$ and several elements that can form compounds with S, i.e., $\mathrm{Na}_{2} \mathrm{~S}, \mathrm{CuS}$ and $\mathrm{PbS}$.

For two mass graves in Rwanda, Amuno and Amuno [22] studied the environmental distribution of a range of nutrients and trace elements, expressed as oxides $\left(\mathrm{SiO}_{2}, \mathrm{Al}_{2} \mathrm{O}_{3}\right.$, $\mathrm{Fe}_{2} \mathrm{O}_{3}, \mathrm{MnO}, \mathrm{MgO}, \mathrm{CaO}, \mathrm{Na}_{2} \mathrm{O}, \mathrm{K}_{2} \mathrm{O}, \mathrm{TiO}_{2}$ and $\mathrm{P}_{2} \mathrm{O}_{5}$ ). They originated from either the environment (e.g., $\mathrm{Fe}_{2} \mathrm{O}_{3}, \mathrm{SiO}_{2}$ and $\mathrm{Al}_{2} \mathrm{O}_{3}$ ) or from mass graves (e.g., $\mathrm{Na}_{2} \mathrm{O}, \mathrm{K}_{2} \mathrm{O}$ and $\left.\mathrm{P}_{2} \mathrm{O}_{5}\right)$ [23].

This study concentrated on determining the reasons behind the variability of eight selected elements, i.e., $\mathrm{Cu}, \mathrm{Pb}, \mathrm{Zn}, \mathrm{S}, \mathrm{K}, \mathrm{Na}, \mathrm{Ca}$ and $\mathrm{P}$, in the upper parts of soil profiles covering mass graves. Altogether, 18 sites were examined, with mainly mass graves from World Wars I and II (further referred to as WW1 and WW2), a parish cemetery, a kirkut (a Jewish cemetery) and a reference site without any graves. Particular attention was given to the element type, age of the burial site, type of soil, field gradient of the site, water balance within the burial horizon and spatial relationship between burials from various time periods.

The results of investigations of mass graves from WW1 and WW2 were compared with those obtained from studying parish cemeteries with military mass graves from WW1 and, to a lesser degree, those without such mass graves.

\section{Study Area}

Soil samples were collected from mass graves from World Wars I and II in southeastern Poland (Figure 1; Table 1), in which mostly fallen soldiers were buried. This area is located in the Western and Eastern Carpathians and their Foreland (the Sandomierz Depression). The samples were collected from 20 cemeteries and a reference site. Each sample is representative (to the best of the author's efforts) of the given cemetery at a depth of approximately $20 \mathrm{~cm}$. If a cemetery was located in a flat lying area, the sample was taken from its centre, but if a burial site was located on an incline (e.g., in Łużna, Hunkowce, Lesko, Przemyśl and Zbylitowska Góra), the sample was taken from its lowermost part in the line of water flow from the cemetery (Table 2). The sample was the collected part from several pits in the line of a mass grave situated on a hillslope. During the sample preparation process, the material was air-dried, shredded and sieved to $<2 \mathrm{~mm}$ in diameter.

The studied grave sites from World War I (WW1) are situated in Bierówka near Jasło, Rajbrot near Żegocina, Łużna and Tarnów-Chyszów, and those from World War II (WW2) are situated in Dukla, Pustków, Rzeszów, Baligród, Przemyśl and Hunkowce (Slovakia) (Figure 1).

Soldiers of various nationalities and fighting armies were put to rest side by side in the studied graves from WW1. During WW2, soldiers from both sides were buried separately in almost all cases, for instance, the Soviets in Rzeszów, Dukla and Pustków, Polish Soviets in Baligród, and Germans in Hunkowce and Przemyśl. Only in a few cases, mainly those concerning executed civilians, did their burials take place at local cemeteries that existed at the time, e.g., in Rymanów. 


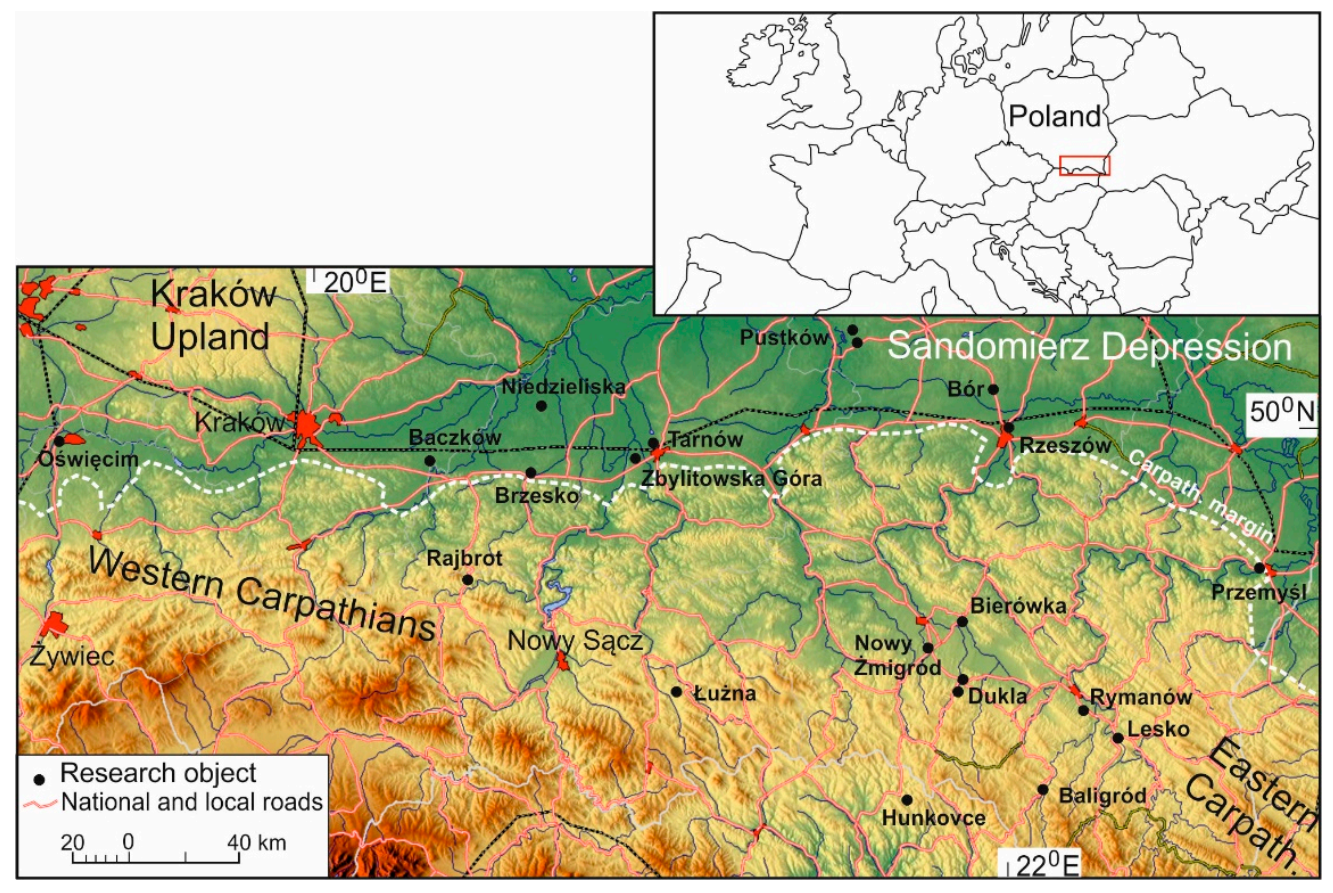

Figure 1. Location of the mass graves studied in southeastern Poland.

Table 1. Type, age and location of the mass gravesites sampled in southeastern Poland.

\begin{tabular}{cr}
\hline Type and Age of the Gravesite & Location of the Gravesites \\
\hline Military mass grave, WW1 & $\begin{array}{c}\text { Bierówka (49.77219; 21.58275), Rajbrot (49.83515; 20.46498), } \\
\text { Łużna (49.71797; 21.06310), Tarnów (50.01662; 20.96112) }\end{array}$ \\
\hline Military mass grave, WW1; other burial sites nearby & $\begin{array}{c}\text { Brzesko (49.97360; 20.60731), Nowy Żmigród (49.60835; 21.53132), } \\
\text { Dukla (49.56103; 21.68150) }\end{array}$ \\
\hline Military mass grave, WW2 & $\begin{array}{c}\text { Dukla (49.50140; 21.68134), Pustków (50.11887; 21.53001), } \\
\text { Rzeszów (50.03796; 22.04332), Baligród (49.34493; 22.28905), } \\
\text { Hunkowce (49.35622; 21.64860), Przemyśl (49.76756; 22.77892) }\end{array}$ \\
\hline Human ashes close to incineration, WW2 & $\begin{array}{c}\text { Auschwitz-Birkenau (currently Brzezinka in the vicinity of Oświecim) } \\
(50.04159 ; 19.16742), \text { Pustków (50.10107; 21.52074) }\end{array}$ \\
\hline Mass grave of executed civilians, WW2 & Bór (50.13269; 21.97336), Zbylitowska Góra (49.98510; 20.89951) \\
\hline Military burial, WW2, on a parish cemetery & Rymanów (49.35622; 21.64860) \\
\hline Jewish cemetery, used before WW2 & Lesko (49.47033; 22.33391) \\
\hline Current cemetery & Niedzieliska (50.08810; 20.63359)
\end{tabular}

Table 2. Characterization of the sites where the samples were collected.

\begin{tabular}{|c|c|c|c|c|}
\hline $\begin{array}{l}\text { Cemeteries and } \\
\text { Reference Site }\end{array}$ & Surface of Grave $\left(\mathrm{m}^{2}\right)$ & SLOPE Gradient (\%) & $\begin{array}{c}\text { The Sampling } \\
\text { Place-a Part of the } \\
\text { Grave (site) }\end{array}$ & $\begin{array}{l}\text { DISTANCE from the } \\
\text { Upper Edge }(\mathrm{m})\end{array}$ \\
\hline $\begin{array}{c}\text { Baczków (reference } \\
\text { site) }\end{array}$ & edge of the forest & floor of valley & centre & - \\
\hline $\begin{array}{c}\text { Baligród WW2, Soviet, } \\
\text { Polish }\end{array}$ & $>3000$ & flat & centre & $20-40$ \\
\hline Bierówka WW1 & 501-1000 & flat & centre & $10-20$ \\
\hline
\end{tabular}


Table 2. Cont.

\begin{tabular}{|c|c|c|c|c|}
\hline $\begin{array}{l}\text { Cemeteries and } \\
\text { Reference Site }\end{array}$ & Surface of Grave $\left(\mathrm{m}^{2}\right)$ & SLOPE Gradient (\%) & $\begin{array}{c}\text { The Sampling } \\
\text { Place-a Part of the } \\
\text { Grave (site) }\end{array}$ & $\begin{array}{l}\text { DISTANCE from the } \\
\text { Upper Edge }(\mathrm{m})\end{array}$ \\
\hline Bór WW2, Jewish & $101-500$ & flat & centre & about 10 \\
\hline Brzesko WW1 & $>3000$ & flat & centre & $>40$ \\
\hline Dukla WW1 & $1001-3000$ & $0-5$ & lowermost & $>40$ \\
\hline Dukla WW2, Soviet & $>3000$ & $0-5$ & lowermost & $20-40$ \\
\hline $\begin{array}{c}\text { Hunkowce WW2, } \\
\text { Wehrmacht }\end{array}$ & $>3000$ & $5-10$ & lowermost & $>40$ \\
\hline Lesko, Jewish & $>3000$ & $5-10$ & lowermost & $>40$ \\
\hline Łużna WW1 & $>3000$ & $5-15$ & lowermost & $>40$ \\
\hline Niedzieliska, cemetery & $>3000$ & flat & centre & $20-40$ \\
\hline Nowy Żmigród WW1 & $1001-3000$ & $0-5$ & lowermost & $20-40$ \\
\hline $\begin{array}{l}\text { Auschwitz-Birkenau } \\
\text { WW2, prisoners of war }\end{array}$ & $>3000$ & flat & centre & $>40$ \\
\hline $\begin{array}{l}\text { Przemyśl WW2, } \\
\text { Wehrmacht }\end{array}$ & $>3000$ & $0-5$ & lowermost & $>40$ \\
\hline Pustków WW2, Soviet & $1001-3000$ & flat & centre & $20-40$ \\
\hline Pustków WW2, ashes & $101-500$ & flat & centre & about 10 \\
\hline Rajbrot WW1 & $1001-3000$ & flat & centre & $20-40$ \\
\hline $\begin{array}{l}\text { Rymanów WW2, } \\
\text { prisoners of war }\end{array}$ & $>3000$ & $<5$ & lowermost & $>40$ \\
\hline Rzeszów, WW2, Soviet & $1001-3000$ & flat & centre & $20-40$ \\
\hline Tarnów WW1 & $>3000$ & flat & centre & $>40$ \\
\hline $\begin{array}{l}\text { Zbylitowska Góra } \\
\text { WW2, Jewish }\end{array}$ & $>3000$ & $10-15$ & lowermost & $>40$ \\
\hline
\end{tabular}

During WW1, war cemeteries were only occasionally located within parish cemeteries, for instance, in Nowy Żmigród or in the vicinity of Jewish cemeteries, such as in Brzesko. Additionally, this study also considers the effects of neighbouring burial sites from various time periods, for instance, a small parish cemetery located close to mass graves from WW1 and WW2 in Dukla. Other sampling sites included large-scale graves of executed civilians in Bór, north of Rzeszów, and Zbylitowska Góra on the Dunajec River near Tarnów. Another set of samples represents places of mass extermination in Oświęcim (Auschwitz-Birkenau) and Pustków, where the ashes of burned people were scattered. Unknown volumes of these ashes were strewn over the land located approximately ten to more than forty metres from the furnaces where the corpses were incinerated. In such a case, a sample was collected from the central part of the area where the ashes were scattered. The ashes were also distributed over more distant, neighbouring fields (Auschwitz-Birkenau and Pustków) and disposed of in the Vistula River (currently Oświęcim) (Table 2). Two non-military cemeteries were also sampled: a Jewish site in Lesko and a present-day site in Niedzieliska, north of Brzesko. For comparison purposes, the soil of a forest nursery (with no graves) in Baczków near Bochnia was included on the list of samples studied as reference material.

The selected burial sites represent landscapes typical of southeastern Poland. The group of grave sites situated at a slightly inclined elevation includes those in Bierówka, Rajbrot, Brzesko and Przemyśl (Table 2). The water table under these mass graves lies very deep underground and is unlikely to have ever reached the surface. The permeability of these burial sites is slightly variable. In the sands of Rajbrot and Brzesko, this parameter is high, and in the silts of Bierówka and Przemyśl, it is slightly lower (Table 3). The upper 
parts of the profiles of these grave sites in the open area are dry or are slightly moist during periods with no precipitation.

Table 3. Characterization of the geographical environments of the sites investigated.

\begin{tabular}{|c|c|c|c|c|c|}
\hline $\begin{array}{l}\text { Cemeteries and } \\
\text { Reference Site }\end{array}$ & No. of Buried & $\begin{array}{l}\text { Soil Parent } \\
\text { Material }\end{array}$ & Soil Texture & Land Cover ${ }^{1}$ & Soil Moisture ${ }^{2}$ \\
\hline $\begin{array}{c}\text { Baczków (reference } \\
\text { site) }\end{array}$ & $\mathrm{n} / \mathrm{a}$ & loams, clays & clayey sand & forest & $\begin{array}{l}\text { periodically } \\
\text { flooded }\end{array}$ \\
\hline Baligród WW2 & $1001-10,000$ & alluvia & $\begin{array}{l}\text { medium and } \\
\text { alluvial loam }\end{array}$ & concrete & locally moist \\
\hline Bierówka WW1 & 501-1000 & $\begin{array}{c}\text { sandstones and } \\
\text { shales }\end{array}$ & silty loam & grass & dry \\
\hline Bór WW2 & $1001-10,000$ & clays & clayey sand & shrubs & periodically moist \\
\hline Brzesko WW1 & $101-500$ & clays & clayey sand & grass & dry \\
\hline Dukla WW1 & 501-1000 & $\begin{array}{c}\text { sandstones and } \\
\text { shales }\end{array}$ & heavy loam & grass & periodically dry \\
\hline Dukla WW2 & over 10,000 & $\begin{array}{c}\text { sandstones and } \\
\text { shales }\end{array}$ & $\begin{array}{l}\text { heavy loam, } \\
\text { construction } \\
\text { rubble }\end{array}$ & shrubs, gravel & periodically dry \\
\hline Hunkowce WW2 & $101-500$ & $\begin{array}{c}\text { sandstones and } \\
\text { shales }\end{array}$ & $\begin{array}{l}\text { heavy loam, rock } \\
\text { rubble }\end{array}$ & grass & locally moist \\
\hline Lesko Jewish & over 10,000 & $\begin{array}{c}\text { sandstones and } \\
\text { shales }\end{array}$ & silty loam & forest, shrubs & periodically dry \\
\hline Łużna WW1 & $1001-10,000$ & $\begin{array}{c}\text { sandstones and } \\
\text { shales }\end{array}$ & heavy loam & forest & locally moist \\
\hline Niedzieliska & 501-1000 & clays & sand & grass, concrete & periodically dry \\
\hline $\begin{array}{c}\text { Nowy Żmigród } \\
\text { WW1 }\end{array}$ & $101-500$ & $\begin{array}{c}\text { sandstones and } \\
\text { shales }\end{array}$ & $\begin{array}{c}\text { medium loam, } \\
\text { sandstone } \\
\text { fragments }\end{array}$ & grass & dry \\
\hline $\begin{array}{c}\text { Auschwitz-Birkenau } \\
\text { WW2, S. * }\end{array}$ & over 10,000 & alluvia, loams & sand (humus) & grass & periodically dry \\
\hline Przemyśl WW2 & $1001-10,000$ & limestones & silty loam & grass & dry \\
\hline Pustków WW2, S. * & $501-1000$ & clays & sand & grass & dry \\
\hline Pustków WW2 & over 10,000 & clays & sand & grass & dry \\
\hline Rajbrot WW1 & $101-500$ & $\begin{array}{c}\text { sandstones and } \\
\text { shales }\end{array}$ & sand & forest & locally moist \\
\hline Rymanów WW2 & $1001-10,000$ & $\begin{array}{c}\text { sandstones and } \\
\text { shales }\end{array}$ & heavy loam & grass & periodically dry \\
\hline Rzeszów, WW2 & $101-500$ & alluvia, loams & sand & grass & dry \\
\hline Tarnów WW1 & $1001-10,000$ & alluvia, loams & silty loam & grass & periodically dry \\
\hline $\begin{array}{c}\text { Zbylitowska Góra } \\
\text { WW2 }\end{array}$ & $1001-10,000$ & alluvia, loams & silty loam, gravel & forest, shrubs & $\begin{array}{c}\text { locally } \\
\text { waterlogged }\end{array}$ \\
\hline
\end{tabular}

${ }^{*}$-ashes; ${ }^{1}$ prevalent; ${ }^{2}$ prevalent (space- and timewise).

The lower parts of the Carpathian hillslopes are occupied by grave sites in Łużna, Hunkowce and Rymanów, and it is only a large kirkut in Lesko that extends from the top of an elevation to the bottom of the valley or to a scarp on its hillslope. The burial sites situated on the slopes of variable-size inclinations in Łużna and Hunkowce are covered by shallow loam layers containing large amounts of rock rubble. The cemeteries in Lesko and Rymanów were established atop silty loam and heavy loam of variable thickness (Table 3). 
The groundwater table under these grave sites rests at a depth of a few metres. Samples were taken from the lower parts of these cemeteries (Table 2).

Mass graves situated on hillslopes that were flattened are represented by two sites in Dukla and one at the cemetery in Nowy Żmigród. The two grave sites of soldiers from WW1 and WW2 in Dukla are situated near each other and, at the same time, downslope of the parish cemetery. Additionally, the gravesite from WW1 lies partly along the line of water flowing from the WW2 gravesite. The area surrounding these grave sites was heavily disturbed during the construction of the cemeteries and a local access road [24]. Heavy loam mixed with construction debris was found there during a sampling campaign (Table 3). The surface of the mass grave from WW2 is divided into sections and covered with fine gravel, whereas the grave site area from WW1 has been planted mainly with grass. The grave site from WW1 in Nowy Żmigród occupies a marginal part of the cemetery situated on a gently rising hillslope. This part of the cemetery lies in a flat area that transitions westwards (in the direction of the Jasło-Nowy Żmigród road) into a gently inclined hillslope and later a more strongly inclined hillslope (Table 2). The grave site area is covered with medium loam containing many fragments of sandstone (Table 3). It is dry and compact in precipitation-free periods.

Sites of mass graves situated at the rear of the studied scarp (but at various distances from it) in Pustków, Rzeszów and Baligród, and in the cemetery in Niedzieliska, were also sampled. Another type of landscape was represented by samples taken from the lowermost section of the mass grave at the bottom of a periodically drained valley in Zbylitowska Góra (Table 2). This valley intersects a landslide front of the Pleistocene terrace of the Dunajec River. Waterlogged fine gravels underlie the upper, silty part of the profile. A mass burial site for Soviet soldiers killed during WW2 and Polish soldiers killed during battles with troops of the Ukrainian Insurgent Army (late 1940s) is situated at the rear of a four-metre-high terrace of the Hoczewka River. The fallen soldiers were buried within alluvial clays (Table 3). The surface of the grave site was divided with low concrete walls into sections, subsequently filled with medium loam carted in from outside the grave site. In turn, the cemetery in Niedzieliska was established on a sandy plain that transitions downward as a 1.5-metre scarp towards a road and local village houses. The water table in the cemetery well is at a depth of approximately $2 \mathrm{~m}$ and rises towards the fore-scarp area. Under these conditions, coffins were buried at a depth of approximately $1.5 \mathrm{~m}$. The ground of the burial sites is therefore often moist due to the presence of capillary water in the sand. The mass graves of Soviet soldiers in Pustków are located on a forested, sandy plain intersected by a road close to the site and those in Rzeszów are located on a high, sandy terrace of the Wisłok River (Table 2). Sections of both grave sites were lined with low concrete walls and filled with sand brought in from the surrounding area. The water table level cannot be high, as it is controlled by the deep road incision in Pustków and the rear side of the scarp in Rzeszów.

Some mass grave sites were established on vast river terraces: in Tarnów-Chyszów and Auschwitz-Birkenau, as well as on a plain of the Kolbuszowa Plateau in Bór. These terraces are highly variable, both vertically and laterally. Silty loams occur in the upper parts of the profiles in Tarnów, whereas in Auschwitz-Birkenau, there are black-coloured soils rich in humus but showing patches of whitish zones, which are probably associated with the presence of incompletely burned bones (Table 3). The groundwater tables within these river terraces are shallow and often oscillate following the level of water in the ditches draining the area. The third grave site mentioned, a mass grave of 3000 Jews, is situated in the forests of Bór on a sandy plain close to another burial site dug within the slope of a dune. The site is surrounded by a low concrete wall, approximately $20 \mathrm{~cm}$ high, and has become overgrown with decorative shrubs. The sands of the upper part of the profile are brownish, which suggests an admixture of clay minerals (Table 3). Downslope, the colour of the sediments in the profile changes to ash-grey, and then finally, the golden colour of pure sand. Near this site in Bór, at a distance of 8-20 m, lies a shallow drainage ditch. The groundwater table is shallow, and its level frequently oscillates. 
The site selected for comparison purposes occupies a natural depression in a terrace of the Raba River in Baczków and is situated close to woodland areas and is utilized by a forest nursery in Niepołomice Forest. The area is periodically flooded. In the dry period when the study was conducted, the upper part of the profile was slightly moist. The sand at this site is brownish and beginning to turn yellow at a depth of $10 \mathrm{~cm}$. In addition to the seedlings of the forest nursery, moss grows in the area.

The study was carried out in May-July 2002. The annual rainfall in Cracow in 2002, totalling $744 \mathrm{~mm}$, was slightly higher than the 1951-2004-period average of $670.4 \mathrm{~mm}$ [25]. The share of rainfall during these three months of 2002 in the annual total for 2002 (41\%) was slightly higher than the multiyear average (39\%). Fluctuations in the groundwater level were associated with multiple summer storms, whose number depended strongly on geographic location. The number of afternoon storms may be given as 15 on average. Approximately 6-8 days without rainfall were noted. In the remaining days, only occasional showers appeared. Intensive storms followed by local inundations occurred in June.

\section{Methods}

After exposing a given soil profile, the organic-rich layer/s $\mathrm{A}_{\mathrm{o}}$ and/or $\mathrm{A}_{1}$ was/were removed, and soil samples were collected from an undisturbed layer situated below the organic-rich layer/s using a spatula. The depth of sampling was approximately $20 \mathrm{~cm}$. At sites where the organic horizon was thick, e.g., in forests, deeper samples were collected but followed the same procedure (i.e., from an undisturbed layer beneath the organic layer). The minimum weight of the soil was approximately $20 \mathrm{mg}$.

Chemical analyses of the collected samples were performed at the chemistry laboratory at Jagiellonian University in Cracow.

The samples were stored in a refrigerator and later in liquid nitrogen. When preparing analytical samples, the soil was dried in a laboratory at $30-35{ }^{\circ} \mathrm{C}$ and later crushed by hand. Final crushing and grinding to a grain fraction of $0.2 \mu \mathrm{m}$ was performed using a Fritsch ball mill. Next, the material was dried following standard procedures. Twenty milligrams of soil sample were accurately weighed into a plastic screw-top tube. The elements contained in the soils were extracted with aqua regia (concentrated $\mathrm{HCl}$ and concentrated $\mathrm{HNO}_{3} \mathrm{vol} / \mathrm{vol} 3 / 1$ ) in a microwave-heated pressure digestion system. Merck "Suprapur" purified acids were used. Lanthanum oxide was also used to eliminate chemical interference. The extraction efficiency was evaluated by regularly analysing the in-house reference soil samples. The sample was heated until dissolved at $220{ }^{\circ} \mathrm{C}$ in PFA and allowed to cool. Upon cooling, the sample was diluted using distilled water. The unit was equipped with a Perkin-Elmer FIAS flow injection system. Chemical analyses of the selected elements were carried out using an atomic absorption spectroscopy (AAS) Perkin Elmer model Analyst 300, with a graphite furnace option (GFAA), including a 6-lamp lamp turret, PC and Winlab software. The standards available from Perkin-Elmer are described in a brochure entitled PE Pure Standards for Atomic Spectroscopy, which is available from Perkin-Elmer as Reprint PEX-AA50B [26,27].

Redox potential (Eh) was measured using platinum electrodes (Pt). The $\mathrm{pH}$ measurements were performed in a solution of $1 \mathrm{~N}$ potassium chloride $(\mathrm{KCl})$.

The $\mathrm{rH}$ value was calculated on the basis of these two values (Clark's scale). It determines the oxidation-reduction potential, similarly to the measured redox potential. It was calculated according to the formula $\mathrm{rH}=\mathrm{Eh}+0.059 \mathrm{pH} / 0.03$. Their values range from 0 to 42 . If they are less than 15, the environment is considered reductive. Values greater than 25 indicate oxidation.

The results of the research were grouped using cluster analysis and Statistica software. The clustering of the eight elements mentioned in relation to their content was carried out according to the Ward criterion using Euclidean distance matrices in the calculations. Another approach to clustering using Statistica software involved taking into consideration all the grave sites and elements studied and grouping the grave sites against the content of 
the selected elements. This clustering also followed the Ward criterion with the Euclidean distance matrices in the calculations.

\section{Results}

The clustering of the eight selected elements according to their content permits their division into three groups and Auschwitz-Birkenau (Figure 2).

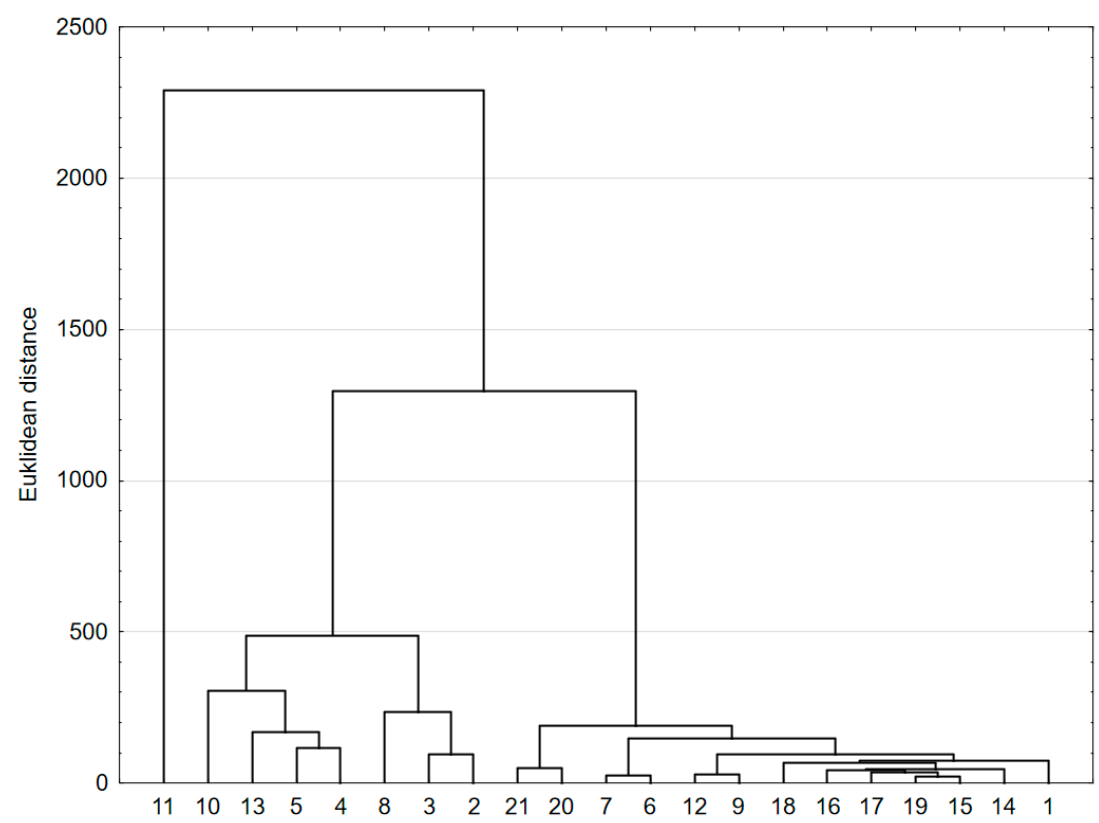

Figure 2. Clustering of mass graves (Ward method, Euclidean distance matrices) considering the selected elements (1—Łużna I * 2-Dukla II; 3-Dukla I; 4-Nowy Żmigród I; 5-Rymanów II; 6-Rajbrot I; 7-Tarnów I; 8-Zbylitowska Góra II; 9-Niedzieliska, cemetery; 10—Baczków; 11— Auschwitz-Birkenau, ashes II; 12—Bierówka I; 13—Hunkowce II; 14—Brzesko I; 15—Lesko, kirkut; 16-Baligród II; 17-Przemyśl II; 18-Pustków, ashes II; 19-Pustków II; 20—Rzeszów II; 21—Bór II (* I, II-WW1 or WW2).

A small group consisted of graves in Dukla $(2,3)$ and Zbylitowska Góra $(8)$ where a large number of people had been buried. The latter site serves as the burial site of about 10,000 people, while the number of soldiers buried at Dukla remains undetermined. In the adjacent valley of death about 100,000 soldiers lost their lives. Both sites are known for clay in the underlayer. At Dukla it is heavy loam, while at Zbylitowska Góra it is silty loam and gravel (Table 3).

High values of $\mathrm{rH}$ (25-31.1) and high concentrations of the studied elements were noted for Dukla. This site is located close to a WW1 cemetery and downslope of a parish cemetery and is characterized by the presence of construction material rubble and metal armament fragments scattered across the loam.

Auschwitz-Birkenau is very different from the rest of the sites in the studied group and is noted for the highest concentrations of elements such as $\mathrm{Ca}$ and $\mathrm{P}$, but not $\mathrm{Cu}$ and $\mathrm{Pb}$ and $\mathrm{Zn}$ (Table 4). At this site, human remains were scattered across a sand river terrace also found at some of the other studied sites: Rajbrot, Brzesko, Pustków and Bór. Drainage ditches are found in close proximity to the former crematoria, and the groundwater level rises during flood periods. Increased humidity in the vicinity favours the reduction of chemical compounds and their migration [28]. Lower values of the rH index for Przemyśl (between 15 and 25) point to variably moist conditions (Table 5). 
Table 4. Statistical parameters of the content $(\mathrm{mg} / \mathrm{kg})$ of the selected chemical compounds analysed in the soils of 20 cemeteries and in Baczków (reference site).

\begin{tabular}{ccccccccc}
\hline \multirow{2}{*}{ Statistical Parameter } & $\mathbf{7}$ & $\mathbf{7}$ & \multicolumn{7}{c}{ Elements } \\
\cline { 2 - 9 } & $\mathbf{Z n}$ & $\mathbf{P u}$ & $\mathbf{S}$ & $\mathbf{N a}$ & $\mathbf{K}$ & $\mathbf{P}$ & $\mathbf{C a}$ \\
\hline Minimum value & 1.0 & 1.0 & 1.1 & 1.6 & 10.1 & 0.9 & 8.9 & 12.3 \\
\hline Maximum value & 112.4 & 25.4 & 245.4 & 123.3 & 155.4 & 52.2 & 952.3 & 1025.5 \\
\hline Arithmetic mean & 30.7 & 5.5 & 30.6 & 28.7 & 43.6 & 25.7 & 169.9 & 95.1 \\
\hline Standard deviation & 36.0 & 3.1 & 26.5 & 31.8 & 34.6 & 20.5 & 18.5 & 215.1 \\
\hline Reference site & 69.4 & 25.4 & 245.4 & 3.0 & 55.1 & 15.1 & 163.3 & 92.4 \\
\hline
\end{tabular}

Table 5. Measured values of $\mathrm{pH}$, Eh and the calculated $\mathrm{rH}$.

\begin{tabular}{|c|c|c|c|}
\hline Cemeteries. & $\mathrm{pH}$ & Eh in Volts & rH \\
\hline Baczków, reference site & 5.96 & 0.3714 & 24.3 \\
\hline Baligród WW2 & 6.53 & 0.5112 & 30.1 \\
\hline Bierówka WW1 & 8.32 & -0.2292 & 9.0 \\
\hline Bór WW2 & 8.72 & 0.2688 & 26.4 \\
\hline Brzesko WW1 & 7.12 & -0.0642 & 12.1 \\
\hline Dukla WW1 & 8.34 & 0.2826 & 26.1 \\
\hline Dukla WW2 & 8.11 & 0.3204 & 26.9 \\
\hline Hunkowce WW2 & 6.42 & 0.4668 & 28.4 \\
\hline Lesko, kirkut & 7.06 & 0.3894 & 27.1 \\
\hline Łużna WW1 & 6.86 & 0.1914 & 20.1 \\
\hline Niedzieliska, cemetery & 6.42 & 0.4788 & 28.8 \\
\hline Nowy Żmigród WW1 & 7.14 & 0.1596 & 19.6 \\
\hline Auschwitz-Birkenau, ashes WW2 & 7.94 & 0.4386 & 30.5 \\
\hline Przemyśl WW2 & 6.59 & 0.3606 & 25.2 \\
\hline Pustków, ashes WW2 & 6.13 & 0.4452 & 27.1 \\
\hline Pustków WW2 & 6.09 & 0.4746 & 28.0 \\
\hline Rajbrot WW1 & 7.56 & 0.2094 & 22.1 \\
\hline Rymanów WW2 & 8.12 & 0.3018 & 26.3 \\
\hline Rzeszów WW2 & 9.33 & 0.2772 & 27.9 \\
\hline Tarnów WW1 & 7.55 & 0.4530 & 20.1 \\
\hline Zbylitowska Góra WW2 & 6.34 & 0.4926 & 29.1 \\
\hline
\end{tabular}

Increased humidity also occurs at Hunkowce, Rymanów and Żmigród Nowy due to their location at the foot of a mountain. The most humid conditions are observed at Baczków, where water collects periodically in area depressions. In the largest studied group, the likelihood of finding the studied elements is high in individual subgroups. For example, small similarities exist between graves located in sandy formations across a local flatland in Rajbrot (6) and an expansive plain around Tarnów (7). The same pattern holds for Niedzieliska (9), Bierówka (12), Rzeszów (20) and Bór (21).

The lowest concentrations of the examined elements were found for relatively impermeable soils (e.g., loams and clay-rich sands) (in reducing environments), as proven by an $\mathrm{rH}$ value of $<15$ in Bierówka (e.g., $\mathrm{P}-8.9 \mathrm{mg} / \mathrm{kg}$; $\mathrm{Ca}-12.3 \mathrm{mg} / \mathrm{kg}$ ) and Brzesko (e.g., $\mathrm{P}-27.2 \mathrm{mg} / \mathrm{kg} ; \mathrm{Ca}-29.9 \mathrm{mg} / \mathrm{kg}$ ). In turn, the cemetery in Łużna is located on a hillslope 
with a variable profile. The locally flat parts of hillslopes may be temporarily moist and result in $\mathrm{rH}$ values below 15 .

Among the elements considered, $\mathrm{Pb}$ occurs in the lowest quantities (Table 4). Its maximum $(25.4 \mathrm{mg} / \mathrm{kg})$ level was noted in Baczków, although this was four times less than that of Zn (112.4 mg/kg) in Dukla WW2 or Cu (85.4 mg/kg) in Dukla WW1 (Figure 3).

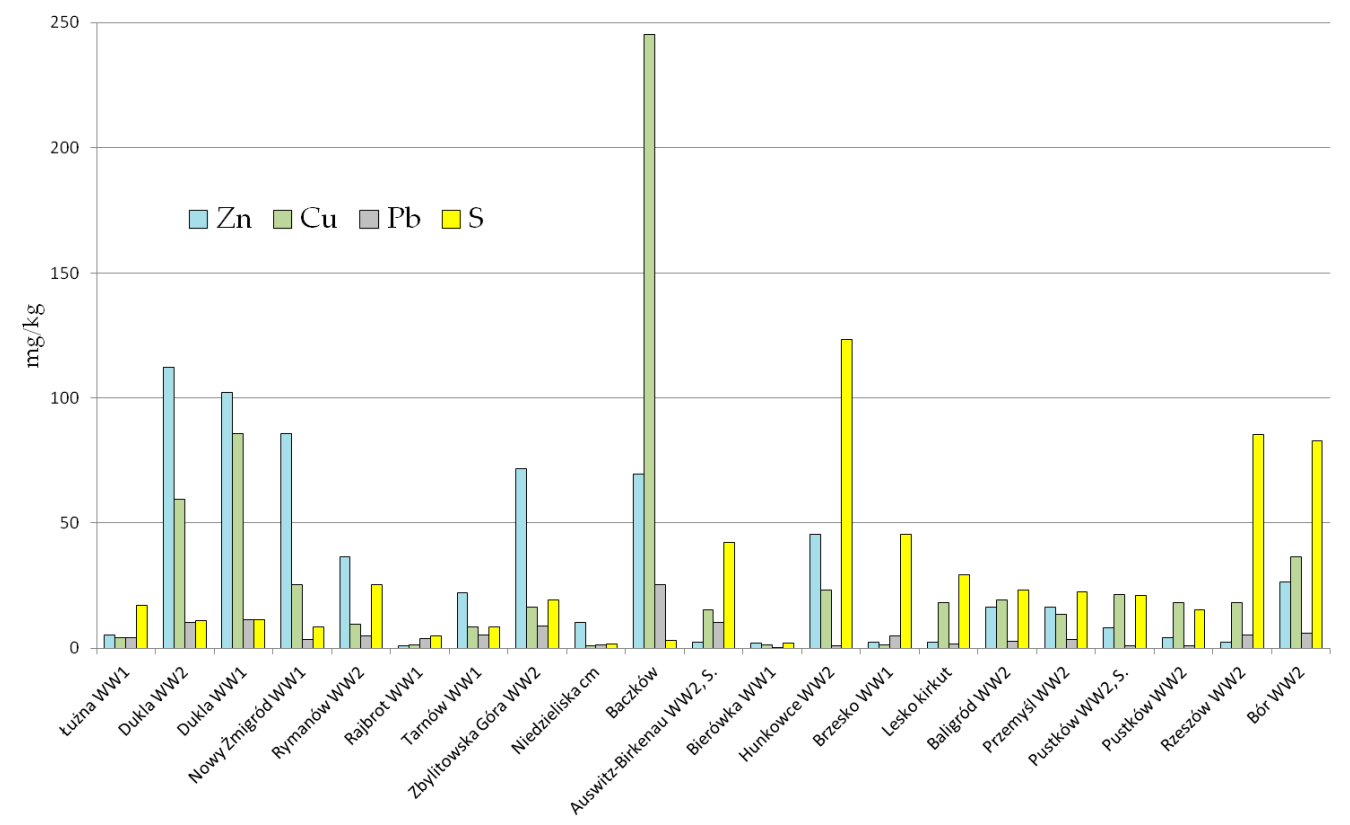

Figure 3. The content of $\mathrm{Zn}, \mathrm{Cu}, \mathrm{Pb}$ and $\mathrm{S}$ in the soil covering the graves studied.

A relatively higher $\mathrm{Pb}$ and $\mathrm{S}$ content is associated with places containing accumulations of human ashes close to the Auschwitz-Birkenau crematorium $(10.3 \mathrm{mg} / \mathrm{kg} ; 42.1 \mathrm{mg} / \mathrm{kg})$, mass graves of civilians in Bór $(5.9 \mathrm{mg} / \mathrm{kg} ; 82.7 \mathrm{mg} / \mathrm{kg})$ and military graves from WW2 in Rzeszów (5.4 mg/kg; $85.3 \mathrm{mg} / \mathrm{kg}$ ), Dukla $(10.3 \mathrm{mg} / \mathrm{kg} ; 10.9 \mathrm{mg} / \mathrm{kg}$ ) and Zbylitowska Góra $(9.0 \mathrm{mg} / \mathrm{kg} ; 19.4 \mathrm{mg} / \mathrm{kg})$. The highest $\mathrm{Pb}$ and $\mathrm{S}$ amounts were determined at sites with different lithologies, both in sand in Bór and silt underlain by gravel in Zbylitowska Góra. Periodically, these places become more humid. At several sites, the contents of $\mathrm{Pb}$ and $\mathrm{S}$ shows very low values, e.g., the military graves from WW1 in Bierówka $(0.1 \mathrm{mg} / \mathrm{kg}$; $1.9 \mathrm{mg} / \mathrm{kg}$ ), Nowy Żmigród (3.4 mg/kg; $8.4 \mathrm{mg} / \mathrm{kg}$ ), Rajbrot $(4.0 \mathrm{mg} / \mathrm{kg} ; 4.9 \mathrm{mg} / \mathrm{kg}$ ) and the cemetery in Niedzieliska $(1.2 \mathrm{mg} / \mathrm{kg} ; 1.6 \mathrm{mg} / \mathrm{kg})$. The content of $\mathrm{Pb}$ yields very low standard deviation values (Table 4 ). Such results point to the possibility of various lead sources. This element can originate either from ambient air (vehicle fuel-derived $\mathrm{Pb}$ ), if the grave site is situated in a larger town and close to a busy road, e.g., in Rzeszów, Hunkowce, or from fragments of rusting crosses scattered on graves (Figure 3).

It is easier to explain the reasons for higher concentrations of $\mathrm{Cu}$ at grave site environments. Relatively higher amounts have been found in soils covering WW2 graves, e.g., in Dukla (WW1-85.4 mg/kg; WW2-59.4 mg/kg). The content of Cu $(245.4 \mathrm{mg} / \mathrm{kg}$ ) is very high in Baczków (reference site). On the other hand, the sulphur content at this point is low, which is only $3 \mathrm{mg} / \mathrm{kg}$. A high Cu content in Baczków can be associated with cutting and planting tools and other devices used in preparing and running the site as a forest nursery.

Sodium clearly dominates in Auschwitz-Birkenau ( $155.4 \mathrm{mg} / \mathrm{kg}$ ) and correlates with high amounts of S-approximately $42.1 \mathrm{mg} / \mathrm{kg}$ (Figure 4). At the remaining sites, the content of $\mathrm{Na}$ is much lower, for instance, in Dukla (WW2-85.3 mg/kg; WW1-92.2 mg/kg), Zbylitowska Góra (WW2-59.4 mg/kg), Pustków WW2, ashes $(56.4 \mathrm{mg} / \mathrm{kg}$ ) and the reference forest nursery in Baczków $(55.1 \mathrm{mg} / \mathrm{kg}$ ). 


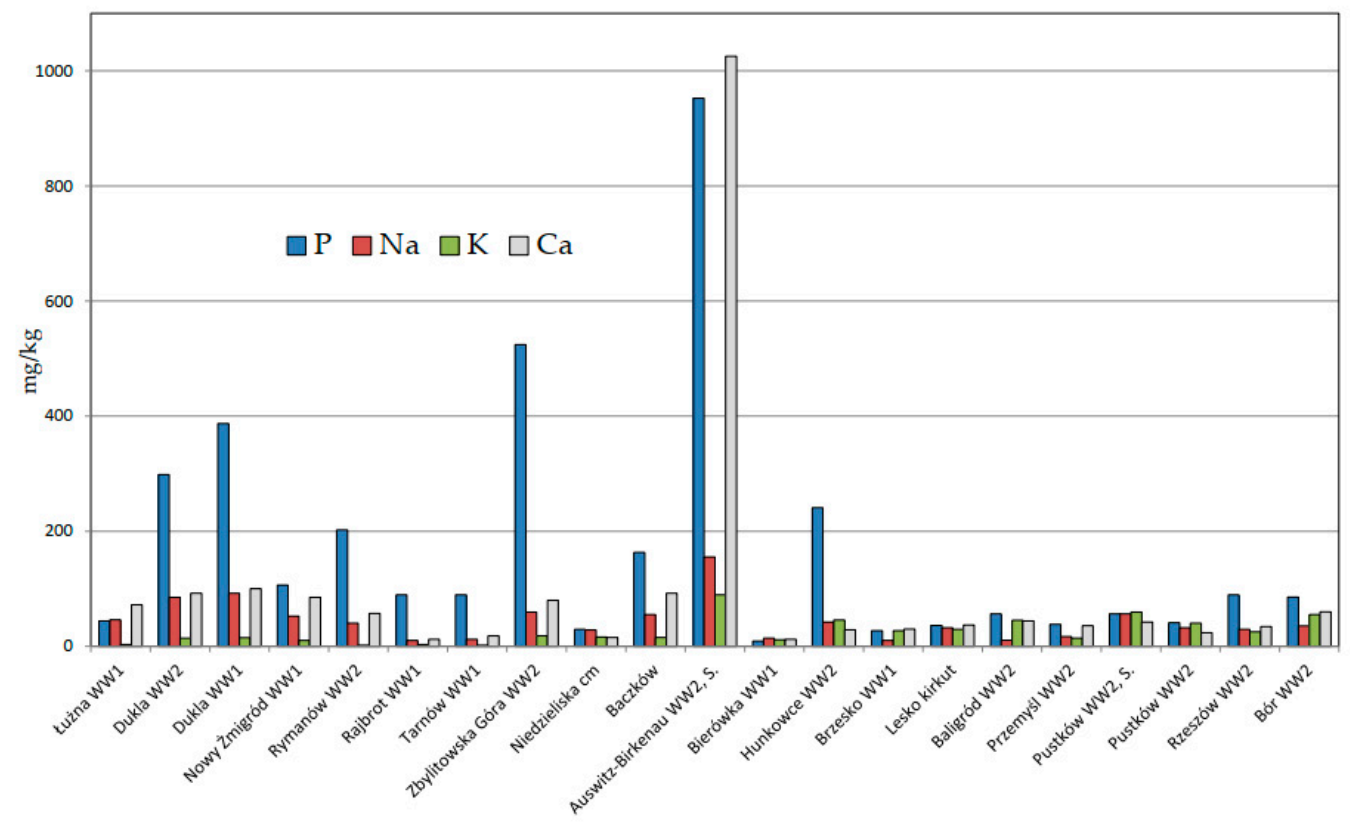

Figure 4. The content of $\mathrm{P}, \mathrm{Na}, \mathrm{K}$ and $\mathrm{Ca}$ in the soil covering the graves studied.

A certain pattern of the Na distribution among grave sites was established: its higher content corresponds to higher numbers of people buried within a relatively small area, and this was observed for Auschwitz-Birkenau, Dukla, Pustków (ashes) and Zbylitowska Góra. Slightly lower Na amounts seem to be associated with the burial sites from WW1, particularly in Łużna $(46.0 \mathrm{mg} / \mathrm{kg}$ ) and Nowy Żmigród $(52.3 \mathrm{mg} / \mathrm{kg})$. Among the elements investigated, Na exhibits an average content and average standard deviation (Table 4). The $\mathrm{K}$ content is also much lower in WW1 mass graves, e.g., in Łużna ( $3.02 \mathrm{mg} / \mathrm{kg})$, Rajbrot $(3.03 \mathrm{mg} / \mathrm{kg})$ and Tarnów $(2.02 \mathrm{mg} / \mathrm{kg})$.

Phosphorus dominates grave sites from WW2, e.g., in Auschwitz-Birkenau (952.25 mg/kg), Dukla (298.36 mg/kg), Zbylitowska Góra (524.36 mg/kg), Hunkowce (241.01 mg/kg) and Rymanów (202.36 mg/kg). Only at a few sites from WW1 (Dukla (386.99 mg/ $\mathrm{kg}$ ) and Nowy Żmigród (106.36 mg/ $\mathrm{kg}$ ) is the content of P comparable with that from WW2 (Figure 4). Higher amounts of the P in question should be attributed, first of all, to the large numbers of victims buried there (Table 3).

Ca content is many times higher close to the crematories in Auschwitz-Birkenau $(1025.52 \mathrm{mg} / \mathrm{kg})$ than at the remaining cemeteries, whereas the sample from Dukla, the next lowest ranked, contains only $100.2 \mathrm{mg} / \mathrm{kg}$ Ca. The results, particularly those concerning $\mathrm{Ca}$, are highly variable, as indicated by relatively high standard deviation values (Table 4). The soils of the Dukla grave site and of the comparative site in Baczków follow the same pattern in the ranking of $\mathrm{Ca}$ : the calcium content was ten times lower at these two sites than at Auschwitz-Birkenau (about $100 \mathrm{mg} / \mathrm{kg}$ ) (Figure 4).

The highest concentrations of $\mathrm{Ca}$ and $\mathrm{P}$ characterize grave sites from WW2, while such relatively high concentrations are only found in the case of two grave sites from WW1, i.e., in Nowy Żmigród and Dukla. These two sites are situated, however, close to other burials. Low levels of P, except for the burials from WW1, were determined in areas where human ashes accumulated during WW2 in Pustków, in the kirkut in Lesko, in the parish cemetery in Niedzieliska and in the mass grave of Soviet soldiers in Pustków. As these grave sites are located within morphological scarps, the decomposition products became transported downward and beyond the burial sites.

The clustering of the grave site based on the total content of the eight considered elements allowed three groups of burial sites to be distinguished, plus a single case of accumulation of human ashes in Auschwitz-Birkenau (Figures 2 and 5). Close to the Auschwitz-Birkenau crematory sites, the elements P and Ca prevail, as they make up 
almost $86 \%$ of these eight elements, whereas the contribution of $\mathrm{Zn}, \mathrm{Pb}, \mathrm{Cu}$ and $\mathrm{S}$ is only $3 \%$. The remaining $7 \%$ is made up of $\mathrm{Na}$ and $\mathrm{K}(4 \%)$.

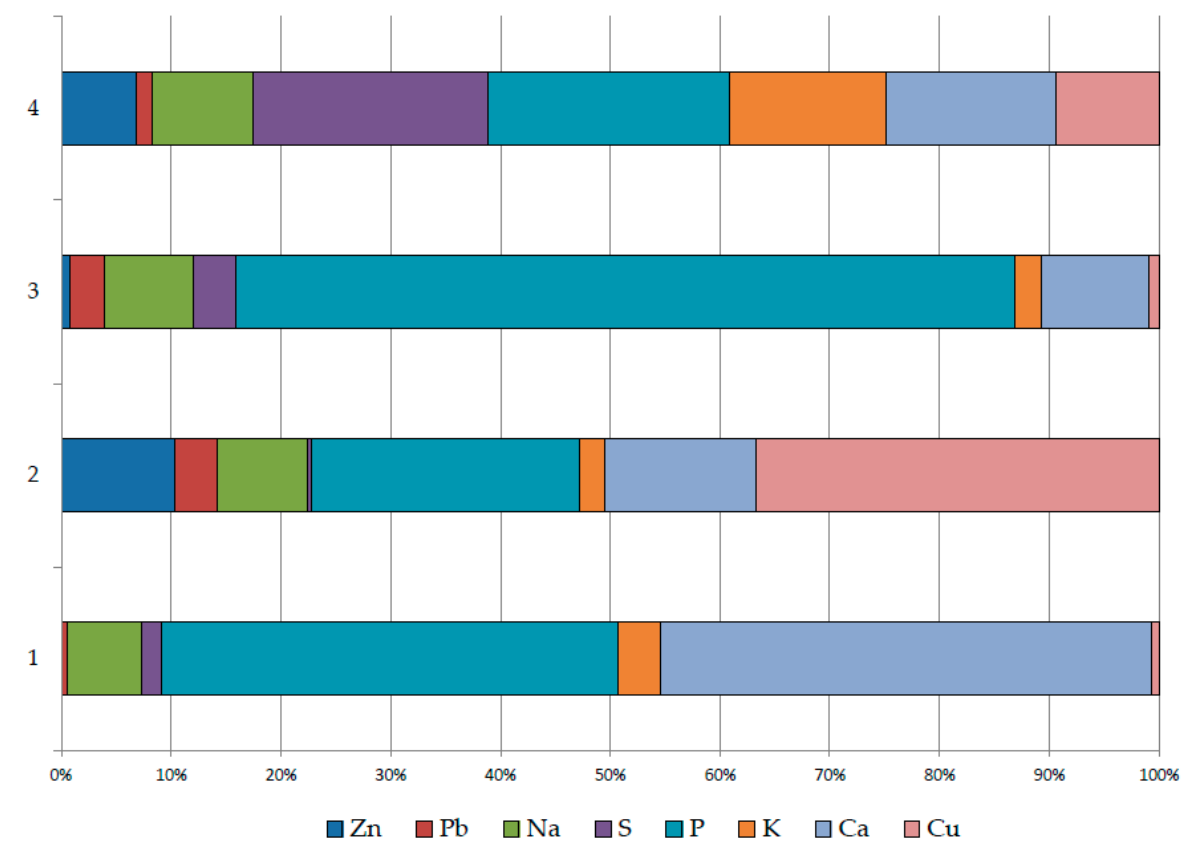

Figure 5. Share of the selected elements ( $\mathrm{Zn}, \mathrm{Pb}, \mathrm{Na}, \mathrm{S}, \mathrm{P}, \mathrm{K}, \mathrm{Ca}$ and $\mathrm{Cu}$ ) in the soils from four sampling sites: river terraces, where human ashes from the Auschwitz-Birkenau (1) concentration camp had been scattered; a forest nursery in Baczków (2, reference site, no graves, edge of Niepołomice Forest); WW1 mass grave in Rajbrot near Bochnia (3) and the WW2 mass grave in Bór near Rzeszów (4).

The second group consists of the graves from Dukla and Zbylitowska Góra, where Ca and P constitute about $60 \%$ in Dukla (WW2, WW1) and 75\% in Zbylitowska Góra of the elements, whereas $\mathrm{Cu}, \mathrm{Zn}$ and $\mathrm{Pb}$ account for approximately $26 \%$ in Dukla and $12 \%$ in Zbylitowska Góra, respectively.

More grave sites belong to the third group, including subsequent burial sites, which represent burials from WW2 in Rymanów and Hunkowce, from WW1 in Nowy Żmigród and the reference site in Baczków. In these places, the contribution of $\mathrm{Cu}, \mathrm{Pb}$ and $\mathrm{Zn}$ varies; for example, in Baczków-50\%, Nowy Żmigród-30\%, Rymanów— $13.2 \%$ and Hunkowce$12 \%$. The share of $\mathrm{Ca}$ and $\mathrm{P}$ varies as well, from $38 \%$ in Baczków, approximately $50 \%$ in Hunkowce and Nowy Żmigród and 68\% in Rymanów.

The fourth group mainly belongs to grave sites from WW1. The remaining sites in this group include the Jewish cemetery in Lesko that was unused after 1945, the parish cemetery in Niedzieliska and six mass graves from WW2: Bór, Rzeszów, Baligród, Przemyśl and two from Pustków. The fourth group is the most diversified given the contributions of the elements considered. At the grave sites in Rajbrot (WW1), Brzesko (WW1) and Bierówka, (WW1), the contribution of $\mathrm{Cu}, \mathrm{Zn}$ and $\mathrm{Pb}$ is low, approximately $5 \%$ (Figure 5 ).

The contribution of P varies widely, from $14 \%$ in Bierówka to $67.8 \%$ in Rajbrot (Figure 5). In the nine places examined, the share in each case amounts to approximately $20 \%$.

Large graves from WW2 contain low contributions of $\mathrm{S}$ and high contributions of $\mathrm{P}$, with a considerable contribution of $\mathrm{Ca}$, particularly in Auschwitz-Birkenau (44.5\%), Dukla and Baczków (reference site). In the remaining sites from WW1, the contribution of $P$ is also significant, for instance, reaching $52 \%$ in Tarnów, including a relatively higher content of $\mathrm{Cu}, \mathrm{Zn}$ and $\mathrm{Pb}$ of approximately $21 \%$, and in Bierówka and Rajbrot reaching $5 \%$.

The grave sites from WW2 reveal the highest diversification of elements. The contribution of $\mathrm{P}$ is relatively higher, e.g., in Auschwitz-Birkenau (41\%), Zbylitowska Góra $(65 \%)$ and Dukla (43.6\%). Only in a few cases (e.g., in Pustków and Przemyśl) are they 
significantly lower (21.3\% and $21.5 \%$, respectively). The contributions of $\mathrm{Cu}, \mathrm{Zn}$ and $\mathrm{Pb}$ in Auschwitz-Birkenau are quite low $(1.2 \%)$, because the Nazis burned undressed corpses.

\section{Discussion}

Phosphorus dominates in soils covering burial sites originating from World War II, which represent a transitional stage of bone decomposition. The leaching of phosphates from the soil into groundwater is independent of soil type, except for predominantly sandy soils, and land-use type $[29,30]$. The very strong bonding of phosphate anions by soil colloids as a result of ligand exchange reactions is a significant cause of phosphorus immobilization [31]. It is the basis of the phosphate method that is applied worldwide in non-destructive archaeology to locate the presence of human dwellings and determine their range. Moldenhawer [32] stressed that $80 \%$ of phosphorus does not leach from the soil. According to archaeologists, the concentration of this element does not depend on the age of the site but on the duration and intensity of land use by its inhabitants [33].

High concentrations and shares of $\mathrm{P}$ and $\mathrm{Ca}$ found in the soils close to the former crematoria of the Nazi concentration camp in Auschwitz-Birkenau are associated with ashes and bone fragments that were not completely incinerated because of the hasty nature of the burning.

Low levels of $\mathrm{P}$ and $\mathrm{Ca}$ were found in most of the graves situated in sandy soils, e.g., in Pustków, as a result of the low amounts of adsorbing clay minerals in such soils and the strong leaching of phosphate anions. The low levels of $S$ in the soils in Bierówka and Niedzieliska, combined with levels of $\mathrm{P}$ and $\mathrm{Ca}$ that are relatively higher than the content found at other burial sites from WW1, are probably the result of efficient drainage in these two areas. Investigations in Niedzieliska were carried out at a small and still active cemetery situated atop a sandy elevation close to the top of its scarp. Thus, the depth of the water table within the cemetery is usually approximately $2-3 \mathrm{~m}$. Equally deep is the water table level at the small WW1 military cemetery in Bierówka. The two mass grave sites differ in terms of the time of their establishment, duration of use, various types of burials performed there and different geographical location. Similar differences in the number of burials, soil characteristics and type of materials used in the construction of coffins, which determine the content of trace metals in the soils, have been previously described for other locations [34].

The presence of heavy metals, particularly at the WW2 sites, is associated with the victims' personal belongings (except at the concentration camps in Auschwitz-Birkenau and Pustków) and fragments of weaponry and military equipment (for instance, knives and mess tins). It is highly probable, according to reports of witnesses, that the corpses of executed Jews, e.g., in Bór and Zbylitowska Góra, contained metal objects, including $\mathrm{Cu}$ as well as other metals. The bullets used by firing squads, military equipment and fragments of armaments and smaller arms are other sources of heavy metals. During this sampling campaign, a rich inventory of metal objects and their fragments was found, even outside the official burial sites. Such artefacts, e.g., mess tins, helmets, bayonets, shells, shell splinters, unexploded shells and spent cartridges, are made of iron and a variety of other metals [35-37]. An undetermined part of the chemical elements found in soils covering the graves must have been released from just such metal objects.

In WW1, fallen soldiers were usually buried twice: after the battle close to the place of their death and later-after exhumation-at official military cemeteries. Although private items were mostly handed over to the families of the dead, part of their personal metal equipment was buried. A characteristic feature is that the fallen soldiers of WW1 were often killed hand-to-hand, mostly in bayonet fighting. For this reason, there are usually few shells in their bodies or in cemetery soils. Another source of some metal elements in the soil of mass graves is medals, usually cast-iron crosses. The soldiers of WW2 were much better equipped, and as such, the weight of the metal armaments, rich in various elements, was incomparably higher per combatant than in WW1. The delivery of these elements into the environment extends the bone decomposition process and retains the decomposition 
products in the burial environment and its vicinity. A study on the number and origin of all heavy metals typically found at these sites is another issue under consideration.

Relatively higher contributions of $\mathrm{Cu}$ and $\mathrm{P}$ were found in soils covering the mass graves from WW2 and, rather exceptionally, in the case of two WW1 mass graves in Dukla and Nowy Żmigród. These exceptions are related to the morphology of the burial sites. The WW1 mass grave in Dukla is situated close to and partly downslope of the currently used parish cemetery and a mass grave from WW2 [38]. In turn, the WW1 mass burial site in Nowy Żmigród is enclosed on three sides by the graves of a communal cemetery. Therefore, in cluster analyses, the differences between these two WW1 cemeteries and WW2 burial sites are insignificant.

There is clearly more P and Ca content at WW2 burial sites, even in environments with a siliciclastic geology, especially at sites where many people were buried in a small area, and the breakdown of hydroxyapatite from human bones continued in the course of the study period. An additional source of carbonates in such places was related to the fact that the Germans, and after the war the Poles, had sprinkled these places with lime. It favoured the retention of bone decomposition products. This issue should be taken into account in the future development of such places. This means that subsequent burials in such places will intensify the chemical processes taking place in the soil, which will increase the diversity of decomposition products and may contribute to an increase in environmental pollution (groundwater). For this reason, places for burials should be chemically identified in advance.

In the soils covering the graves studied, samples were taken below the humus layer. However, due to excavation, the substrate of the burial sites is mixed. The presence of even a small amount of humus, e.g., in sandy soils, increases the content of phosphorus [39]. A much higher content of calcium phosphate occurs also in other soils, such as rendzinas and black earth [40]. A similar rule applies to soils with a high $\mathrm{pH}$. In my studies conducted in the dry period, the $\mathrm{pH}$ values did not vary significantly. Only at the Baczków site, occurring in an area with a shallow aquifer, was the $\mathrm{pH}$ low at 5.96 (Table 5). Levels of $\mathrm{P}$ and $\mathrm{Ca}$ and heavy metals in Baczków approximate the respective values noted for large burial sites. This similarity points to a considerable range of changes brought about by the presence of mass graves that affect the environment irrespective of its features. Large mass graves can have an adverse effect on the natural environment. The reference site in Baczków (fenced, forest nursery) represents a wet, periodically flooded area. Human activity at this site, in addition to tree planting, includes the felling of trees and shrubs. The high content of $\mathrm{Cu}$ at the Baczków site is probably related to tree felling with chainsaws.

Adsorption of phosphorus is important also in environments with a low $\mathrm{pH}$ and high content of clay minerals and iron [41,42]. Another example of a positive correlation between the adsorption capacity of $\mathrm{P}$ and clay content was demonstrated by Falcao [43]. In general, the fine fraction of particles in the soil is less conducive to the leaching of phosphorus compounds. According to Zheng [44], the greatest mobility of phosphorus (in gleysolic soil) occurs in sandy loam, loam, clay loam, clay and heavy clay soil, respectively.

\section{Conclusions}

A higher content of $\mathrm{P}, \mathrm{Ca}$ and Na corresponds to a higher number of people buried within a relatively small area, and this is observed in the case of Auschwitz-Birkenau and Zbylitowska Góra. This is readily observable in the case of Auschwitz-Birkenau, where the contribution of $\mathrm{P}$ and $\mathrm{Ca}$ is high and reaches $86 \%$ of all the elements tested, whereas the contribution of $\mathrm{Cu}, \mathrm{Zn}$ and $\mathrm{Pb}$ is low, at only $1.2 \%$. A follow-up study carried out in deeper sections of the profiles, not only in Auschwitz-Birkenau, can provide new information.

At the small, active cemetery in Niedzieliska, clustered together with cemeteries from WW1, the concentration of the elements studied is relatively low, as is the case for small burial sites from WW1, e.g., in Bierówka and Rajbrot (Figure 2). The major elements found in Niedzieliska include P (26\%) and Na (25.2\%, followed by K $(14.2 \%), \mathrm{Ca}(13.0 \%)$ and, together, $\mathrm{Cu}, \mathrm{Zn}$ and $\mathrm{Pb}(11 \%)$. 
In soils near the mass grave in Rajbrot there is a high content of $\mathrm{P}$ and $\mathrm{Ca}$, as in soils close to the crematories of the Nazi concentration camp in Auschwitz-Birkenau (Figure 5), where unburned bone fragments (visible under a microscope) remain in places where the ashes were placed. The reason for the high Ca content around the Rajbrot grave is the chemical composition of the weathered sediments under the soil layer, which are sandstones containing carbonate cement. The presence of calcium in the immediate bedrock promotes the retention of bone decomposition products in the natural environment. There is also a distinct dependency between the amount of the elements and the number of people buried in mass graves from WW2 and military graves from WW1 situated close to other burial sites (cemeteries and kirkuts).

Higher concentrations of $\mathrm{Cu}, \mathrm{Zn}$ and $\mathrm{Pb}$ occur in soils covering WW2 burial sites with multiple corpses, including soldiers and civilians, irrespective of environmental conditions. Phosphorus and Ca contribute the most to the total of the elements studied in the case of the largest mass graves from WW2, in contrast to the low level of $S$, which is usually less than $5 \%$. High contributions of P occur sporadically in sandy soils covering burial sites from WW1, e.g., 68\% in Rajbrot and 52\% in Tarnów in silty loam, whereas the contribution of $\mathrm{S}, \mathrm{Zn}, \mathrm{Cu}$ and $\mathrm{Pb}$ is low-only a few percent. Relatively higher contributions of $\mathrm{Cu}$ in soil covering WW2 graves must be associated with higher amounts of metal equipment and other artefacts possessed by soldiers and the executed civilians. A surprisingly high content of copper in the soil of the Baczków reference site (forest nursery) can be explained by present-day agrotechnical work performed by forestry staff.

The diversification of the contributions of the elements studied depends on their kind, the type and age of the burial site, the type of soil, the hillslope inclination and water content of the site and the close locations of mass graves and cemeteries.

WW2 burial sites show higher differentiation in the amount of the selected elements. This may result from the decomposition process and various conditions found in mass grave environments, but such a hypothesis should also be tested in the future.

Further investigations should concentrate on determining the relationship between the decomposition products leached from the burial sites and compounds in the natural environment, such as oxides-hydroxides of $\mathrm{Fe}$ and $\mathrm{Mn}$, mineral-organic complexes and clay minerals. Another issue worth studying includes the identification of specific stages of decomposition leading to the emission of gaseous products.

Funding: This research was partially funded by statutory research programmes at the Pedagogical University of Krakow, Internal Number BN.610-192/PBU/2020.

Institutional Review Board Statement: Not applicable.

Informed Consent Statement: Not applicable.

Data Availability Statement: Data sharing not applicable.

Acknowledgments: This study was carried out using the author's own research resources. I would like to express my sincere thanks to Mariusz Kolber and his fellow scientists, as well as analytical chemists from Jagiellonian University in Krakow and to Andrzej Skowroński, a mineralogist from the AGH University of Science and Technology in Krakow, for their kind help and discussion.

Conflicts of Interest: The author declares no conflict of interest.

\section{References}

1. Rodriguez, W.C., III; Bass, W.M. Decomposition of Buried Bodies and Methods That Aid in Their Location. J. Forensic Sci. 1985, 30, 836-852. [CrossRef]

2. Environmental Agency. Assessing the Groundwater Pollution Potential of Cemetery Developments; UK Environmental Agency: Bristol, UK, 2002; pp. 1-20.

3. Fineza, A.G.; Marques, E.A.G.; Bastos, R.K.X.; Betim, L.S. Impacts on the Groundwater Quality within a Cemetery Area in Southeast Brazil. Soils Rocks São Paulo 2014, 37, 161-169.

4. White, E.M. Cautionary note on soil phosphate data interpretation for archaeology. Am. Antiq. 1978, 43, 507-508. [CrossRef]

5. Broadbent, N. Phosphate analysis in archaeology: Anthropological uses of an old method. Soc. Am. Archaeol. Proc. 1981, 42, 1-16. 
6. Lillios, K.T. Phosphate Fractionation of Soils at Agroal, Portugal. Am. Antiq. 1992, 57, 495-506. [CrossRef]

7. Eidt, R.C. A rapid chemical field test for archaeological site surveying. Am. Antiq. 1973, 38, 206-210. [CrossRef]

8. Bethell, P.H.; Máté, I. The use of soil phosphate analysis in archaeology: A critique. In Scientific Analysis in Archaeology; Henderson, J., Ed.; Oxford University Committee: Oxford, UK, 1989; Volume 19, pp. 1-29.

9. Terry, R.E.; Nelson, S.D.; Carr, J.; Parnell, J.; Hardin, P.; Jackson, M.W.; Houston, S.D. Quantitative phosphorus measurement: A field test procedure for archaeological site analysis at Piedras Negras, Guatemala. J. Archaeol. Sci. 2000, 27, 449-462. [CrossRef]

10. Cook, S.F.; Heizer, R.F. Studies on the Chemical Analysis of Archaeological Sites; University of California Press: Berkeley, CA, USA, 1965; Volume 2, pp. 1-102.

11. Panak, H.; Wojnowska, T. Phosphorus migration deep into sandy and loamy soil columns at an intensive percolation with water. Rocz. Glebozn. 1981, 32, 67-73.

12. Barba, L.; Ortiz, A. Analisis quimico de pisos de occupacion: Un caso etnografico en Tlaxcala, Mexico. Lat. Am. Antiq. 1992, 3, 63-82. [CrossRef]

13. Parnell, J.J.; Terry, R.E.; Golden, C. Using in field phosphate testing to rapidly identify middens at Piedras Negras, Guatemala. Geoarcheology 2001, 16, 855-873. [CrossRef]

14. Parnell, J.J.; Terry, R.E.; Nelson, Z. Soil chemical analysis applied as an interpretive tool for ancient human activities in Piedras Negras, Guatemala. J. Archaeol. Sci. 2002, 29, 379-404. [CrossRef]

15. Żychowski, J. Geological aspects of decomposition of corpses in mass graves from WW1 and 2, located in SE Poland. Environ. Earth Sci. 2011, 64, 437-448. [CrossRef]

16. Brzeziński, W.; Dulinicz, M.; Kobyliński, Z. Zawartość fosforu w glebie jako skaźnik dawnej działalności ludzkiej. Kwart. Hist. Kult. Mater. 1983, 31, 277-297.

17. Szymkiewicz-Dąbrowska, D. Przemiany trudno rozpuszczalnych fosforanów glinu, żelaza, miedzi, manganu i cynku w wodnych roztworach wybranych związków nieorganicznych. Acta Acad. Agric. Tech. Olst. Agric. 1996, 62 (Suppl. SA), 1-81.

18. Arrhenius, O. Die Phosphatfrage. In Zeitschrift fur Pflanzenernahrung, Dundung und Bodenkunde; Wiley Online Library: Stockholm, Sweden, 1929; Teil A, 14; pp. 185-194. [CrossRef]

19. James, P. Soil variability in the area of an archaeological site near Sparta, Greece. J. Archeol. Sci. 1999, 26, 1273-1288. [CrossRef]

20. Żychowski, J. Impact of cemeteries on groundwater chemistry: A review. Catena 2012, 93, 29-37. [CrossRef]

21. Fiedler, S.; Breuer, J.; Pusch, C.M.; Holley, S.; Wahl, J.; Ingwersen, J.; Graw, M. Graveyards-Special landfills. Sci. Total Environ. 2012, 419, 90-97. [CrossRef] [PubMed]

22. Amuno, S.A.; Amuno, M.M. Geochemical Assessment of Two Excavated Mass Graves in Rwanda: A Pilot Study. Soil Sediment Contam. Int. J. 2014, 23, 144-165. [CrossRef]

23. Rudovicaa, V.; Viksnaa, A.; Actinsa, A.; Zarinab, G.; Gerhardsb, G.; Lusensc, M. Investigation of Mass Graves in the Churchyard of St. Gertrude's, Riga, Latvia. Interdiscip. Archaeol. Nat. Sci. Archaeol. 2011, II, 39-46. [CrossRef]

24. Fiedler, S.; Schneckenberger, K.; Graw, M. Characterization of soils containing adipocere. Arch. Environ. Contam. Toxicol. 2004, 47, 561-568. [CrossRef]

25. Urząd Statystyczny w Krakowie. Rocznik Statystyczny Krakowa; Statistical Office in Kraków: Kraków, Poland, 2005.

26. Oliveira, E.D. Sample Preparation for Atomic Spectroscopy: Evolution and Future Trends. J. Braz. Chem. Soc. 2003, 14, 174-182. [CrossRef]

27. Welz, B.; Sperling, M. Atomic Absorption Spectrometry, 3rd ed.; Wiley-VCH: New York, NY, USA, 1999.

28. Żychowski, J. Zawartość pierwiastków w wybranych elementach środowiska przyrodniczego otoczenia masowego grobu położonego w Puszczy Niepołomickiej (Concentration of chemical elements in some components of natural environment in area of mass graves situated in Niepołomicka forest). Acta Sci. Pol. Form. Circumiectus 2009, 3, 43-56.

29. Margowski, Z.; Bartoszewicz, A. Migracja związków fosforowych do wód gruntowych w różnych warunkach glebowych. Pr. Nauk. Akad. Ekon. im. Oskara Langego we Wroctawiu. 1975, 91, 87-92.

30. Bartoszewicz, A. Stężenie niektórych jonów w wodach gruntowych gleb uprawnych. Rocz. Akad. Rol. Pozn. 1985, 159, 3-28.

31. Kowalik, P. Ochrona Środowiska Glebowego; Wydawnictwo Naukowe PWN: Warszawa, Poland, 2001; p. 261.

32. Moldenhawer, K. Przydatność w archeologii metody fosforanowej i fluorowej oraz innych metod. Wiadomości Archeol. 1963, $29,323-327$.

33. Balke, B. W sprawie przydatności metody fosforanowej do badań archeologicznych. Archeol. Pol. 1975, 20, 161-174.

34. Amuno, S.A.; Oluwajana, A.O. Comparative assessment of trace metals in soils associated with casket burials: Towards implementing green Burias. Eurasian J. Soil Sci. 2014, 3, 65-76.

35. Stephan, C. The roses of Picardy, the poppies of the Somme: An anthology of the Great War, or how the war made landscapes. J. Gard. Hist. 1997, 17, 214-220. [CrossRef]

36. Fabiansson, N.; The Archaeology of the Western Front. 1914-1918. 2004. Available online: http://w1.865.telia.com/ \{\}u8651708 0/BattlefieldArchaeology/ArkeologENG_3B.html (accessed on 15 January 2021).

37. Żychowski, J. Wptyw Masowych Grobów z I i II Wojny Światowej na Środowisko Przyrodnicze (Impact of WW 1 and 2 Mass Graves on the Natural Environment); Wydawnictwa Instytutu Geografii Uniwersytetu Pedagogicznego w Krakowie: Kraków, Poland, 2008; p. 305.

38. Żychowski, J. The impact of cemeteries in Kraków on the natural environment-Selected aspects. Geogr. Pol. 2011, 4, 13-32. [CrossRef] 
39. Moskal, S.T.A.N.I.S.Ł.A.W.; Delczewa-Walewa, D.O.N.K.A. Przemiany fosforanu potasu w różnych typach gleb. Rocz. Glebozn. 1969, 20, 119-134.

40. Mackenzie, A.F.; Amer, S.A. Reactions of iron, aluminium and calcium phosphates in six Ontario soils. Plant Soil 1964, 21, 17-25. [CrossRef]

41. Dent, B.B. The Hydrogeological Context of Cemetery Operations and Planning in Australia. Ph.D. Thesis, The University of Technology, Sydney, Australia, 2002; p. 453. Available online: https://opus.lib.uts.edu.au/bitstream/10453/20259/6/02Whole. pdf (accessed on 15 January 2021).

42. Żychowski, J.; Pawlikowski, M.; Lach, J. Produkty dekompozycji szczątków organicznych na przykładzie masowego grobu w Niepołomicach. Kwart. Geol. 2006, 32, 203-225.

43. Falcão, N.P.D.S.; Silva, J.R.A. Características de adsorção de fósforo em alguns solos da Amazônia Central. Acta Amaz. 2004, 34, 337-342. [CrossRef]

44. Zheng, Z.; Parent, L.E.; MacLeod, J.A. Influence of soil texture on fertilizer and soil phosphorus transformations in Gleysolic soils. Can. J. Soil Sci. 2003, 83, 395-403. [CrossRef] 